\title{
Caries experience and associated risk factors in Venezuelan 6-12-year-old schoolchildren
}

\author{
Alejandra GARCÍA-QUINTANA ${ }^{(a)}$ \\ Stephanie DÍAZ(a) iD \\ Oriana COVA(a) \\ Sara FERNANDES(a) \\ Maria Angélica AGUIRRE(a) iD \\ Ana María ACEVEDO(b) iD \\ (a) Central University of Venezuela, Faculty of \\ Dentistry, Caracas, Venezuela. \\ (b) Central University of Venezuela, Research \\ Institute "Raúl Vincentelli", Faculty of \\ Dentistry, Caracas, Venezuela.
}

Declaration of Interests: The authors certify that they have no commercial or associative interest that represents a conflict of interest in connection with the manuscript.

\section{Corresponding Author:}

Alejandra García Quintana

E-mail: alejandra.garcia.quintana@gmail.com

https://doi.org/10.1590/1807-3107bor-2022.vol36.0026

Submitted: February 16, 2020

Accepted for publication: July 14, 2021

Last revision: November 11, 2021
Abstract: This research aims to provide updated information on caries experience and associated risk factors in children 6-12 years old. A cross-sectional and descriptive study design was carried out with a non-probabilistic, convenient sample of 209 children male and female. Clinical examinations were performed by calibrated dental students following WHO detection criteria. Caries indices $\mathrm{dmft}$ and DMFT were calculated. Caries Risk Assessment data was collected using an adapted CAMBRA instrument; following the International Caries Care guidelines. Descriptive statistics were performed to analyze the results and Chi-square test, Contingency Coefficient (C) and Corrected Typified Residues were calculated to determine the association between variables. $58 \%$ of the total population had dental caries lesions in its more severe stages (cavitation) and $42 \%$ were apparently healthy (AHS) without any cavitated lesions. The mean $\mathrm{dmft}$ index was $1.34 \pm 1.93$, and the mean DMFT index was $0.63 \pm 1.22$. Lesion severity remained between 1-2 teeth affected on both dentitions. A statistically significant association $(p=0.035)$ between the health condition and toothbrushing was stablished with a degree of dependence of $C=0.144$. A positive standardized residual of 2.1 was evident for schoolchildren that experience caries lesion that never brush their teeth and AHS that brushed their teeth more than once. No association $(p=0.081)$ was found between health condition and intake of sugary snacks and beverages. A severe dental caries experience with a statistically significant association between the health condition and toothbrushing with fluoridated toothpaste $1450 \mathrm{ppm}>1$ a day and a positive correlation in schoolchildren that experience caries lesion that never brush their teeth.

Keywords: Dental Caries; Risk Factors; Tooth, Deciduous; Dentition, Permanent.

\section{Introduction}

Dental caries affects humans without distinction of gender, age, socioeconomic status, or race, although the individuals most vulnerable to this disease are in the lowest socioeconimic classes. ${ }^{1,2}$ Dental caries is defined by consensus as a biofilm-mediated, diet modulated, multifactorial, non-communicable, dynamic disease resulting in net mineral loss of dental hard tissues, determined by biological, behavioral, psychosocial, 
and environmental factors. ${ }^{3}$ Although the presence of aciduric bacteria in the dental biofilm capable of lowering the $\mathrm{pH}$ in conditions of severe dysbiosis is the cornerstone of the disease, the participation of external factors such as high intake of sugar is necessary for the disease to settle and progress. The disease in the absence of treatment progresses until the appearance of a lesion that could be detected in a clinical stage by the localized mineral loss of hard tissues. ${ }^{4}$

In addition, the dental caries lesion is understood as a dynamic interaction process that occurs between the tooth surface and the dental biofilm, in which there is an imbalance between the net mineral loss and gain; this imbalance at a given moment can favor the demineralization process. ${ }^{4,5}$ The lesion is considered the late sign of dental caries disease; ${ }^{4}$ however, its first expression at a subclinical stage can be arrested or remineralized when the balance among the physiological events that occur in the dental biofilm is restored. ${ }^{6}$

Dental caries is a generalized problem among young children according to the information published by the World Health Organization (WHO), and it is estimated that approximately 60 to $90 \%$ of school children have this pathology worldwide. ${ }^{7}$ Venezuela is not an exception and, despite the few local scientific reports, ${ }^{8-12}$ it is known that the disease prevalence ranges from 60 to $80 \%$, being school-age children the most affected. Dental caries management is a costly expense for the governments and is beyond the financial capabilities of the majority of low-income countries, especially because the financial resources are strongly limited for public dentistry. ${ }^{13}$

Caries risk assessment (CRA) is one of the bases in patient-centered caries lesion management. CRA establishes the probability to develop carious lesions over a certain time period or the likelihood that there will be a change in size or activity of lesions already present. ${ }^{14}$ There is a lot of controversy about which of the multiple factors involved in the disease can really impact its onset and how can they be measured. On the other hand, there is not sufficient designed and validated tools that accurately and reliably evaluate the cause of this complex disease. Some tools rely on reasoning-based manual standardized checklists, such as the American Academy of Pediatric Dentistry's Caries Risk Assessment Form (CRAF) ${ }^{15}$ and the Caries Management by Risk Assessment (CAMBRA) philosophy. ${ }^{16}$ Others use algorithms in software programs; as examples there are the Cariogram, a software that calculates the "chance to avoid caries" using 10 caries-related risk factors, ${ }^{17}$ the National University of Singapore model, which is a statistical model built through epidemiological data collected from preschoolers in Singapore to expresses chance of developing caries as a percentage,$^{18}$ and the PreViser ${ }^{\mathrm{SM}}$ an online tools that based on patient history and clinical data calculates caries risk, in a central software unit. ${ }^{19}$

Knowledge of the oral health status and dental caries risk assessment in schoolchildren are an essential element for developing, planning, organizing, and controlling dental care programs and practice. ${ }^{20}$ Limited official information is available addressing the above problems; therefore, the aim of this study focused on providing risk factors associated with dental caries disease in children 6 to 12 years old, and updating the information on caries experience in this age group. The results will be useful to further develop a large-scale project based on intervention strategies and prevention programs that improve the oral health of this vulnerable sector.

\section{Methodology}

\section{Design and sample selection}

This was a cross-sectional and descriptive design; carried out during the period January-March 2020. The total universe of children registered in elementary schools ( $1^{\text {st }}$ to $6^{\text {th }}$ grade) in Chacao Municipality was 9,133 children for the year 2003-2004, ${ }^{21}$ being the closer statistical data obtained from municipality authorities. The selection of the school was based first and most on being a public school in proximity to the healthcare public service where personal safety for the researchers could be guarantee. Second, the school had a number of students that could provide a representative sample of schoolchildren in that age group. The schoolchildren enrolled in the selected public school, according to Graffar-Mendez Castellano Scale, ${ }^{22}$ were from a medium-low socioeconomic status. A non-probabilistic, convenient sample of 400 6-12-year-old children was selected for the study. 
This sample constituted the totality of $1^{\text {st }}$ to $6^{\text {th }}$ grade schoolchildren enrolled in the period 2019-2020 from the selected public school, and represented $4.4 \%$ of the total children registered in Chacao Municipality in 2003-2004. Out of the 400 children, 209 (52.3\%) boys and girls provided a written consent form signed by a parent or guarding accepting the participation in the study. The study protocol and consent form were reviewed and approved by the Bioethical Committee of the Faculty of Dentistry, Central University of Venezuela (CB-139-2021).

\section{Clinical examination and caries lesion index calculation}

The clinical examinations were carried out on children at school premises. A total of 5 dental students participated in data collection and one calibrated dental student (AGQ) performed all the exams based on the criteria reported by the WHO. ${ }^{23}$ The examiner's reliability was assessed with kappa statistics (Cohen's kappa intra $=0.95) .{ }^{24}$ The remaining students recorded the data. The visual detection of dental caries lesions was performed under natural light, using a wooden tongue depressor. The exam was done following the biosafety regulations of the Faculty of Dentistry, Central University of Venezuela. To record the data, the evaluation was carried out in sequential order by quadrant, first evaluating primary teeth followed by permanent teeth. From the recorded data, the $\mathrm{dmft}$ and DMFT caries indexes were calculated for both primary and permanent dentition.

The WHO criteria comply the following recommendations: ${ }^{23}$ a) each tooth was visually examined for the presence of cavitated lesions, fillings, and teeth lost due to caries, b) if there was doubt about the patient's response in relation to lost teeth and it was not possible to obtain accurate information, the examiner followed his clinical judgment, and c) each code was clearly dictated to avoid errors in the annotation.

\section{Caries risk factors assessment}

The data for Caries Risk Assessment (oral hygiene practices, dietary habits, physiological and structural conditions, among others) was collected using the CAMBRA instrument ${ }^{25}$ adapted to semantic characteristics by the Pediatric Dentistry Department of the Faculty of Dentistry, Central University of Venezuela. The information recorded in the evaluation instrument was taken by the same group of students that performed the clinical evaluation. CAMBRA tool uses three categories for caries risk, but in practice it is probably quicker, easier, and sufficient to focus on correctly identifying patient at the extremes of the risk spectrum because those at the low and high risk categories have clear management needs. Therefore, the individual risk of each patient in this study was determined according the International Caries Care (ICC) ${ }^{26}$, classifying the sample as low and high risk.

\section{Statistical analysis}

All data were entered and analyzed using Excel Software and the Statistical Package for the Social Sciences version 20 software (SPSS Inc, Chicago, USA). Descriptive statistics (mean, frequencies, percentage, correlations) were performed and used for result interpretation, according to the variables studied. Statistical comparison between groups was done using paired Student's t-test. In order to determine the association among variables, a Pearson's Chi-square non-parametric test was used. Since Chi-square test only determines the existence of association between variables but it does not yield results in the meaning and magnitude of the association, it was decided to measure the degree of association using the Contingency Coefficient (C). Finally, to verify how the variables contribute to the association (correlation), the corrected typified residuals analysis was carried out. Significance was considered with a $\mathrm{p}<0.05$.

\section{Results}

The demographic variables show a fairly equitable distribution of the population in terms of gender and age.

\section{Dental caries experience}

The results indicated that $58 \%$ of the total population showed dental caries lesions in its more severe stages (cavitation) and $42 \%$ were apparently healthy without any cavitated lesions (Table 1). In relation to the 
primary dentition, $47.4 \%$ of schoolchildren presented cavitated lesions, as opposed to the permanent dentition, where only $27.4 \%$ presented lesions. The percentages of schoolchildren with affected primary dentition among the age groups $6-7,8$, and 9 years were greater than $50 \%$. On the other hand, the percentage of schoolchildren with affected permanent dentition increased 2.3 times in the age ranges of 6-7 and 8 years and remain unchanged until the age of 12 years (Table 1 ).

The mean $\mathrm{dmft}$ index of the schoolchildren was $1.34 \pm 1.93$ and the mean DMFT index was $0.63 \pm 1.22$. By age group, the $\mathrm{dmft}$ index ranged from 2.65 to 1.28 for children aged $6-7,8$, and 9 years, and a significant increase was observed when the $\mathrm{dmft}$ index was compared between 6-7 and 9 years $(p=0.005)$. On the contrary, the average DMFT ranged from 0.21 to 1.96 in children from 6 to 12 years old. A significant 3.4-fold increase was observed between DMFT in 6-7 and 8 years old $(p=0.05)$, as well as the DMFT in 6-7 and 11-12 years $(p=0.008)$. A 3-fold increase was noted between the DMFT in 10 and 11-12 years, however the difference was not significant. No significant variation $(p>0.05)$ was observed between the males and females regarding the $\mathrm{dmft}$; however, the girls had a slightly higher DMFT index (Table 2).

When analyzing the indices according to severity (Table 3), it was observed that, among the sample that had cavitated lesions, children with 1-2 teeth affected in the primary dentition represented $49.6 \%$, with 3-4 teeth affected were $14.9 \%$, and with more than 5 teeth with cavitation, $16.5 \%$. In the permanent dentition a different pattern was observed: $27.3 \%$ of the children showed 1 to 2 cavitated teeth, and $19.8 \%$ had a lesion in 3 to 4 teeth.

\section{Determination of dental caries risk factors}

Eighty-nine percent of the schoolchildren were identified as high risk for dental caries disease development or caries lesion progression; however, $11 \%$ of the total population was classified as low risk (Figure).

Table 1. Dental caries prevalence by age group in primary and permanent dentition.

\begin{tabular}{|c|c|c|c|c|c|c|c|c|c|c|c|c|c|c|c|}
\hline \multirow[t]{2}{*}{ Age } & \multirow[b]{2}{*}{$n$} & \multicolumn{2}{|c|}{$\begin{array}{l}\text { Apparently } \\
\text { healthy } \\
\text { schoolchildren }\end{array}$} & \multicolumn{2}{|c|}{$\begin{array}{c}\text { Schoolchildren } \\
\text { that experience } \\
\text { caries lesion }\end{array}$} & \multirow{2}{*}{$\begin{array}{c}\text { Schoolchildren } \\
\text { with primary } \\
\text { dentition } \\
n\end{array}$} & \multicolumn{2}{|c|}{$\begin{array}{l}\text { Schoolchildren } \\
\text { without } \\
\text { caries lesion } \\
\text { in primary } \\
\text { dentition }\end{array}$} & \multicolumn{2}{|c|}{$\begin{array}{c}\text { Schoolchildren } \\
\text { with caries } \\
\text { lesion in } \\
\text { primary } \\
\text { dentition }\end{array}$} & \multirow{2}{*}{$\begin{array}{c}\text { Schoolchildren } \\
\text { with permanent } \\
\text { dentition } \\
\text { n }\end{array}$} & \multicolumn{2}{|c|}{$\begin{array}{c}\text { Schoolchildren } \\
\text { without caries } \\
\text { lesion in } \\
\text { permanent } \\
\text { dentition }\end{array}$} & \multicolumn{2}{|c|}{$\begin{array}{l}\text { Schoolchildren } \\
\text { with caries } \\
\text { lesion in } \\
\text { permanent } \\
\text { dentition }\end{array}$} \\
\hline & & $n$ & $\%$ & $\mathrm{n}$ & $\%$ & & $n$ & $\%$ & $n$ & $\%$ & & $n$ & $\%$ & $n$ & $\%$ \\
\hline $6-7$ & 34 & 8 & 23.5 & 26 & 76.5 & 34 & 9 & 26.5 & 25 & 73.5 & 33 & 29 & 00.0 & 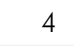 & 11.8 \\
\hline 8 & 45 & 13 & 28.9 & 32 & 71.1 & 45 & 15 & 33.3 & 30 & 66.7 & 45 & 33 & 73.3 & 12 & 26.7 \\
\hline 9 & 43 & 17 & 50.0 & 26 & 60.5 & 43 & 18 & 11.9 & 25 & 58.1 & 43 & 30 & 69.8 & 13 & 30.2 \\
\hline 10 & 41 & 21 & 51.2 & 20 & 48.8 & 30 & 16 & 39.0 & 14 & 34.1 & 41 & 28 & 68.3 & 10 & 31.7 \\
\hline $11-12$ & 46 & 29 & 67.4 & 17 & 36.9 & 16 & 11 & 23.0 & 5 & 10.9 & 46 & 31 & 67.4 & 15 & 32.6 \\
\hline $6-12$ & 209 & 88 & 42 & 121 & 58 & 168 & 69 & 33 & 99 & 47.4 & 208 & 151 & 72.6 & 57 & 27.4 \\
\hline
\end{tabular}

Table 2. Mean dmft and DMFT indices by age and gender.

\begin{tabular}{lccccccccc}
\hline \multirow{2}{*}{ Age } & \multicolumn{3}{c}{ Masculine } & \multicolumn{3}{c}{ Femenine } & \multicolumn{2}{c}{ Total } \\
\cline { 2 - 10 } & $\mathrm{n}$ & $\mathrm{dmft}$ & DMFT & $\mathrm{n}$ & $\mathrm{dmft}$ & DMFT & $\mathrm{n}$ & dmft $^{*}$ & DMFT* $^{*}$ \\
\hline $6-7$ & 19 & $2.89 \pm 2.63$ & $0.40 \pm 1.06$ & 15 & $2.33 \pm 2.49$ & $0.17 \pm 0.41$ & 34 & $2.65 \pm 2.49^{\mathrm{a}}$ & $0.21 \pm 0.72^{\mathrm{c}}$ \\
8 & 19 & $2.05 \pm 2.56$ & $0.58 \pm 1.30$ & 26 & $2.08 \pm 1.98$ & $0.81 \pm 44$ & 45 & $2.07 \pm 2.24$ & $0.71 \pm 1.38^{\mathrm{d}}$ \\
9 & 26 & $1.08 \pm 1.54$ & & 17 & $1.59 \pm 1.50$ & $0.65 \pm 17$ & 43 & $1.28 \pm 1.55^{\mathrm{b}}$ & $0.51 \pm 0.96$ \\
10 & 21 & $1.00 \pm 1.57$ & $0.48 \pm 1.08$ & 20 & $0.55 \pm 0.86$ & $0.85 \pm 35$ & 41 & $0.78 \pm 1.30$ & $0.66 \pm 1.22^{\mathrm{e}}$ \\
$11-12$ & 20 & $0.20 \pm 0.68$ & $0.90 \pm 1.48$ & 16 & $0.31 \pm 0.77$ & $1.00 \pm 47$ & 46 & $0.26 \pm 0.74$ & $1.96 \pm 1.47^{\dagger}$ \\
$6-12$ & 105 & $1.38 \pm 2.05$ & $0.53 \pm 1.14$ & 104 & $1.30 \pm 1.79$ & $0.73 \pm 30$ & 209 & $1.34 \pm 1.93$ & $0.63 \pm 1.22$ \\
\hline
\end{tabular}

*Statistical comparison (paired T Test) between age groups: $\mathrm{dmft}$ (pvalue); $a, b=0.005 ;$ DMFT (pvalue) c,d =0.05; DMFT (pvalue) $c, f=0.008$; DMFT (pvalue) $e, f=0.42$. 
Table 3. Mean dmft and DMFT indices distribution according to severity by age.

\begin{tabular}{|c|c|c|c|c|c|c|c|c|c|c|c|c|c|}
\hline \multirow{3}{*}{ Age } & \multirow[b]{3}{*}{$\mathrm{n}$} & \multirow{2}{*}{\multicolumn{2}{|c|}{$\frac{d m f t}{1-2}$}} & \multirow{2}{*}{\multicolumn{2}{|c|}{$\begin{array}{l}\mathrm{dmft} \\
3-4\end{array}$}} & \multirow{2}{*}{\multicolumn{2}{|c|}{$\begin{array}{l}\mathrm{dmft} \\
\geq 5\end{array}$}} & \multirow{2}{*}{\multicolumn{2}{|c|}{$\begin{array}{c}\text { DMFT } \\
1-2\end{array}$}} & \multirow{2}{*}{\multicolumn{2}{|c|}{$\begin{array}{c}\text { DMFT } \\
3-4\end{array}$}} & \multirow{2}{*}{\multicolumn{2}{|c|}{$\begin{array}{c}\text { DMFT } \\
\geq 5\end{array}$}} \\
\hline & & & & & & & & & & & & & \\
\hline & & $n$ & $\%$ & $n$ & $\%$ & $\mathrm{n}$ & $\%$ & $n$ & $\%$ & $\mathrm{n}$ & $\%$ & $\mathrm{n}$ & $\%$ \\
\hline $6-7$ & 34 & 12 & 35.3 & 2 & 5.9 & 10 & 29.4 & 3 & 8.8 & 1 & 2.9 & 0 & 0 \\
\hline 8 & 45 & 15 & 33.3 & 9 & 20.0 & 6 & 13.3 & 5 & 11.1 & 7 & 15.6 & 0 & 0 \\
\hline 9 & 43 & 17 & 39.6 & 4 & 9.3 & 3 & 7.0 & 10 & 23.3 & 3 & 7.0 & 0 & 0 \\
\hline 10 & 41 & 12 & 29.3 & 1 & 2.3 & 1 & 2.3 & 8 & 19.5 & 5 & 12.2 & 0 & 0 \\
\hline $11-12$ & 46 & 4 & 8.7 & 2 & 4.3 & 0 & 0 & 7 & 15.2 & 8 & 17.4 & 0 & 0 \\
\hline $6-12$ & 209 & 60 & 49.6 & 18 & 14.9 & 20 & 16.5 & 33 & 27.3 & 24 & 19.8 & 0 & 0 \\
\hline
\end{tabular}

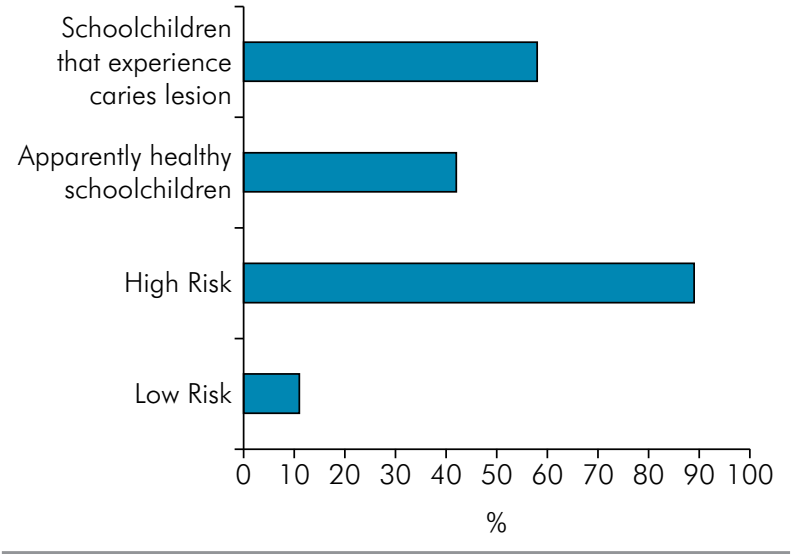

Figure 1. Dental Caries Risk Factors in schoolchildren.

\section{Dental caries experience and associated risk factors: oral hygiene practices and dietary habits}

Out of the total number of patients evaluated (209), $121(57.9 \%)$ were affected by the disease in a cavitated state, and of these, 16 (13.2\%) never brushed their teeth and $105(86.8 \%)$ brushed more than once a day. The remaining 88 patients $(42.1 \%)$ were apparently healthy and out of these total, 4 (4.5\%) never brushed and 84 (95.5\%) brushed more than once a day (Table 4$)$.
In relation to dietary habits, more than half of the total children $(63.6 \%)$ had a high intake of sugary snacks and beverages. Out of the 121 kids recorded as schoolchildren that experience caries lesion, 83 (68.6\%) consumed sugary snacks and beverages 3 times a day and $31.4 \%$ had a low frequency intake. On the other hand, for the apparently healthy group, $56.8 \%$ consumed sweet snacks 3 times a day or more, and $43.2 \%$ had a low consumption (Table 4).

The results of the Chi-square independent test showed a statistically significant association between the health condition and toothbrushing $(\mathrm{p}=0.035)$. In contrast, no association $(p=0.081)$ was found between health condition and intake of sugary snacks and beverages (Table 5). The degree of dependence between the variables health condition and toothbrushing according to the contingency correlation coefficient $(C)$ was $C=0.144$, with a $\mathrm{p}=0.035$ (Table 6).

To verify the variables that contributed to the association between the health condition and toothbrushing, the corrected typified residuals analysis was used. The difference between the observed and expected counts show a positive standardized residual of 2.1 for schoolchildren with caries lesions that

Table 4. Distribution of oral hygiene practices and dietary habits in schoolchildren.

\begin{tabular}{|c|c|c|c|c|c|c|c|c|c|c|}
\hline \multirow{3}{*}{ Oral health htatus } & \multirow[b]{3}{*}{$\mathrm{n}$} & \multirow[b]{3}{*}{$\%$} & \multicolumn{4}{|c|}{ Oral Hygiene Practices } & \multicolumn{4}{|c|}{ Dietary Habits } \\
\hline & & & \multicolumn{2}{|c|}{$\begin{array}{l}\text { Tooth Brushing } \\
<1 \text { a day }\end{array}$} & \multicolumn{2}{|c|}{$\begin{array}{l}\text { Tooth Brushing } \\
\geq 1 \text { a day }\end{array}$} & \multicolumn{2}{|c|}{$\begin{array}{l}\text { Low frequency intake } \\
\text { of sugary snacks } \\
\text { and beverages }\end{array}$} & \multicolumn{2}{|c|}{$\begin{array}{l}\text { Sugary snacks and } \\
\text { beverages intake } \\
\geq 3 \text { times a day }\end{array}$} \\
\hline & & & $\mathrm{n}$ & $n$ & $\%$ & $\%$ & $\mathrm{n}$ & $\%$ & $\mathrm{n}$ & $\%$ \\
\hline Apparently healthy schoolchildren & 88 & 42.1 & 4 & 50 & 56.8 & 95.5 & 38 & 43.2 & 50 & 56.8 \\
\hline Schoolchildren that experience caries lesion & 121 & 57.9 & 16 & 83 & 68.6 & 86.8 & 38 & 31.4 & 83 & 68.6 \\
\hline Total & 209 & 100 & 20 & 133 & 63.6 & 90.4 & 76 & 36.4 & 133 & 63.6 \\
\hline
\end{tabular}


Table 5. Results of the statistical analysis using Chi-square test.

\begin{tabular}{|c|c|c|c|c|c|c|c|c|c|c|}
\hline \multirow[b]{2}{*}{ Variable } & \multicolumn{2}{|c|}{ Value } & \multicolumn{2}{|c|}{ gf } & \multicolumn{2}{|c|}{$\begin{array}{l}\text { Bilateral asymptotic } \\
\text { significance }\end{array}$} & \multicolumn{2}{|c|}{$\begin{array}{l}\text { Bilateral exact } \\
\text { significance }\end{array}$} & \multicolumn{2}{|c|}{$\begin{array}{l}\text { Unilateral exact } \\
\text { significance }\end{array}$} \\
\hline & $\begin{array}{l}\text { Health } \\
\text { condition } \\
\text { and oral } \\
\text { hygiene } \\
\text { practice }\end{array}$ & $\begin{array}{l}\text { Health } \\
\text { condition } \\
\text { and } \\
\text { dietary } \\
\text { habit }\end{array}$ & $\begin{array}{l}\text { Health } \\
\text { condition } \\
\text { and oral } \\
\text { hygiene } \\
\text { practice }\end{array}$ & $\begin{array}{c}\text { Health } \\
\text { condition } \\
\text { and } \\
\text { dietary } \\
\text { habit }\end{array}$ & $\begin{array}{l}\text { Health } \\
\text { condition } \\
\text { and oral } \\
\text { hygiene } \\
\text { practice }\end{array}$ & $\begin{array}{c}\text { Health } \\
\text { condition } \\
\text { and } \\
\text { dietary } \\
\text { habit }\end{array}$ & $\begin{array}{l}\text { Health } \\
\text { condition } \\
\text { and oral } \\
\text { hygiene } \\
\text { practice }\end{array}$ & $\begin{array}{l}\text { Health } \\
\text { condition } \\
\text { and } \\
\text { dietary } \\
\text { habit }\end{array}$ & $\begin{array}{l}\text { Health } \\
\text { condition } \\
\text { and oral } \\
\text { hygiene } \\
\text { practice }\end{array}$ & $\begin{array}{c}\text { Health } \\
\text { condition } \\
\text { and } \\
\text { dietary } \\
\text { habit }\end{array}$ \\
\hline Pearson Chi-square & $4.433^{\mathrm{a}}$ & $3.054^{a}$ & 1 & 1 & 0.035 & 0.081 & & & & \\
\hline Continuity correction ${ }^{b}$ & 3.487 & 2.566 & 1 & 1 & 0.062 & 0.109 & & & & \\
\hline Likelihood ratio & 4.816 & 3.042 & 1 & 1 & 0.028 & 0.081 & & & & \\
\hline Fisher test & & & & & & & 0.54 & 0.109 & 0.28 & 0.055 \\
\hline Linear by linear association & 4.412 & 3.039 & 1 & 1 & 0.36 & 0.081 & & & & \\
\hline $\mathrm{n}$ valid cases & \multicolumn{2}{|c|}{209} & & & & & & & & \\
\hline
\end{tabular}

Table 6. Result of the calculated contingency correlation coefficient

\begin{tabular}{lcc}
\hline Variable & Value & Approximate significance \\
\hline Nominal by nominal & 0.144 & 0.035 \\
$N$ valid cases & 209 & \\
\hline
\end{tabular}

Table 7. Results of corrected typified residuals.

\begin{tabular}{|c|c|c|c|}
\hline \multirow[b]{2}{*}{ Health condition } & \multicolumn{2}{|c|}{ Oral hygiene practices } & \multirow[b]{2}{*}{ Total } \\
\hline & $\begin{array}{l}\text { Toothbrushing } \\
<1 \text { a day }\end{array}$ & $\begin{array}{c}\text { Toothbrushing } \\
\geq 1 \text { a day }\end{array}$ & \\
\hline \multicolumn{4}{|c|}{ Apparently healthy schoolchildren } \\
\hline Count & 4 & 84 & 88 \\
\hline Expected count & 8.4 & 79.6 & 88.0 \\
\hline$\%$ within health condition & 4.5 & 95.5 & 100 \\
\hline Standardized residual & -2.1 & 2.1 & \\
\hline \multicolumn{4}{|c|}{ Schoolchildren that experience caries lesion } \\
\hline Count & 16 & 105 & 121 \\
\hline Expected Count & 11.6 & 109.4 & 121.0 \\
\hline$\%$ within health condition & 13.2 & 86.8 & 100 \\
\hline Standardized residual & 2.1 & -2.1 & \\
\hline \multicolumn{4}{|l|}{ Total } \\
\hline Count & 20 & 189 & 209 \\
\hline Expected count & 20 & 189 & 209.0 \\
\hline$\%$ within health condition & 9.6 & 90.4 & 100 \\
\hline
\end{tabular}

never brushed their teeth and apparently healthy schoolchildren that brushed their teeth more than once. On the contrary, a negative standardized residual of -2.1 was observed for schoolchildren with caries lesions that brushed their teeth more than once and apparently healthy schoolchildren that never brushed their teeth (Table 7).

\section{Discussion}

The results of the present study are limited to a cross-sectional evaluation due to the nature of the data. A sample size of 209 schoolchildren was well thought out and in agreement among the researchers as enough to analyze this study's main objective of "provide an association between risk factors in children 6 to 12 years old and dental caries disease". Additionally, possible biases associated with the detection criteria could have impacted the results, which must be considered when interpreting the results. The detection criteria used was selected after a consensus of the participant researchers since it was the only method that allowed comparisons with other local or national studies carried out in the country regarding caries experience.

This study showed a severe state of dental caries disease expressed as cavitated lesions and the association with risk factors in a group of Venezuelan schoolchildren. The results discussed exclude caries lesions in less severe stages or non-cavitated, because the detection method used considers as a dental caries only cavitated lesions. Therefore, the observed results do not reflect the real situation of the disease. For these reasons and analysis purposes the population without cavities was called "Apparently Healthy Schoolchildren" (AHS).

Caries prevalence indicated that $58 \%$ of the schoolchildren between 6 and 12 years had at least one cavitated caries lesion in either primary or permanent dentitions. When contrasting these results 
with those of Morón and Cordova ${ }^{12}$ in a national study who report a prevalence of $55 \%$ for the same age group, we observed that the prevalence showed only slight changes after 12 years. Three questions can be drawn from these results: a) Has there really been a change in the prevalence of cavitated lesions in this age group nationwide, or the difference is just a simple coincidence due to the sample used?; b) Does a well selected population within a few municipalities or states could be considered to evaluate the national status of the disease and allow the design of less costly investigations with accurate criteria?; and finally, (c) Are there any factors that might be controlling the lesion development and progression in this population?

It was unexpected that the caries prevalence did not increase, despite the fact that in the last 12 years a deep deterioration in social determinants had been occurring in Venezuela. In particular, affected conditions such as quality of life, inadequate eating patterns, limited access to health services, poor water sanitizing measures, low wages, and impoverished education could influence the individual susceptibility to develop dental caries with consequent lesion progression. However, the aforesaid seems to be not very influential in the studied population. This behavior in the prevalence pattern suggests that there might be other factors to consider that could be overcoming the effect that the deterioration in social conditions is capable of producing. Such factors include: tooth brushing with fluoridated toothpastes ${ }^{4,5,27}$ that are widely used in the country, the quality of saliva, and the dietary components available (fiber, proteins, fats, and prebiotics). Nonetheless, as we comment above, it is important that this assumption be verified with well-designed and low-cost clinical trials.

From the results regarding disease severity, it is impressive that $73.5 \%$ of schoolchildren between 6 and 7 years old and more than half of the children aged 8 and 9 already had the disease in its most severe stage, expressed as cavitation, in their primary dentition; although lesion severity remained between 1 and 2 cavitated teeth. This indicates that the disease was established early in life, and due to the lack of treatment and control it progressed affecting the hard tissue (enamel) with the consequent lesion development (non-cavitated) that advanced to cavitation. This could be associated with the inadequate early introduction of dietary components ( $>5-10 \%$ of sugar intake) before 2 years of age, ${ }^{28}$ which could favor a shift in the commensal dental biofilm microbiota and lead to the establishment of a modified bacterial ecosystem (dysbiosis) that will be the driving force behind negative health outcomes. ${ }^{4}$

Permanent dentition was also addressed on the same schoolchildren, thus sharing the same dysbiotic conditions in their dental biofilm. The results of this study showed that the proportion of children 6-7 years with cavitated lesions in their primary dentition is 6.2 times greater than the proportion of those same children who had permanent teeth affected with caries lesion. Even though it has been reported in the literature that the presence of dental caries lesions in the primary dentition is a predictor of future lesions in the young permanent dentition, ${ }^{29}$ the results seem to indicate that both the disease severity and its presence (dmft/DMFT 1-2 cavities) are similar in permanent and primary dentitions, but the proportion of schoolchildren with caries in their permanent dentition is significantly lower $(p<0.005)$.

In order to analyze this situation even further, the total number of schoolchildren with first permanent molars erupted was calculated. It was noted that out of 33 schoolchildren with permanent dentition, $17(52 \%)$ had the first permanent molars erupted and only 4 (23\%) of them had cavitated lesions. Possible explanations could be suggested for this opposing results. First, dental caries disease in primary dentition often affects the cervical area of the buccal surface of the upper incisors and second and first molars. ${ }^{30}$ In contrast, in the permanent dentition, the upper incisors are generally not affected and the lesion primarily appears in the occlusal surface of molars. ${ }^{31}$ In particular, lower incisors are located in proximity to the excretory duct of the submandibular and sublingual salivary glands, therefore constantly exposed to a saliva flow that would favor the spontaneous remineralization of any possible caries lesions that develop, thus reducing the progression to cavitation. Second, in children with severe disease, the lesion progresses more 
rapidly in primary dentition compared to permanent dentition due to the enamel structure, morphology, and composition. ${ }^{30,32}$ Also, as supported by our results, the primary teeth are exposed early to severe disease conditions (dysbiosis in the dental biofilm) for a longer period of time. In addition, it is important to consider the effect of sample size on the results.

The mean $\mathrm{dmft}$ and DMFT indexes support what was previously discussed and were in agreement with national and local studies by Morón et al. ${ }^{12}$ and Montero et al..$^{33}$ The increment of 3.4-fold observed between children 6-7 and 8 years old, as well as of 3.0-fold increase between those 10 and 12 years old corresponds to the ages of first and second permanent molar eruptions, with the consequent exposure of more surfaces at risk to dysbiotic oral environment conditions without any treatment.

Dental caries experience is evidently seen in the studied sample where the disease was in a severe stage and slowly progressed into cavitated lesions. Moreover, when analyzing the risk level and how the disease expresses, a striking result appeared. Results demonstrated that $58 \%$ were affected by dental caries, using cavity as indicator of the disease. However it was established by risk determination that $89 \%$ of the population was identify as high risk, either with non-cavitated, cavitated, clinically non-detected lesion, or just the disease presence, and only $11 \%$ of the children could be assumed as healthy. These results clearly indicate that the prevalence only reflects the disease in its more severe state when the cavitated lesion is already present, and that only taking this parameter as an indicator to assess the disease is not enough because it produces a major underreport. Therefore, it was important to analyze the factors that might have determined the lesion expression and progression in this population. The association between oral hygiene practices (toothbrushing with fluoridated toothpaste) and dietary habits (intake of sugary snacks and beverages) with the population's health and disease condition (dental caries experience) were evaluated.

For this sample, it was found that toothbrushing with fluoridated toothpastes once or more a day had a significant association $(p=0.035)$ and positive correlation with the AHS. This result is similar to that of the study of Llena et al. ${ }^{34}$ where it was found that toothbrushing with fluoridated toothpastes at least twice a day was associated with significantly lower values of DMFT. On the one hand, toothbrushing by itself is not as effective to control lesion progression ${ }^{35}$, nonetheless it is important to consider its effect on the disorganization and removal of the dental biofilm, which allows salivary clearance of accumulated harmful compounds (acids) and reduction of bacterial mass density. On the other hand, the use of fluoridated toothpastes creates a rich fluoride environment that will encourage remineralization by acceleration and enhancement of lost mineral depositions on demineralized enamel. ${ }^{36}$ Both mechanical biofilm removal and the use of fluoride are important strategies to protect the dental structure and, by some means, control lesion progression. However, it is essential to asses dental caries disease in order to successfully shift dysbiotic conditions to a healthy state, as it is known that the dental caries lesion is the clinical expression of a complex process likely to occur when there is a drift of $\mathrm{pH}$ in the biofilm, as a consequence of increased carbohydrate availability or reduced salivary clearance. ${ }^{4}$

Diet, specifically fermentable carbohydrates, have been considered as main factors that modulate the shift from symbiosis to dysbiosis of microbial interactions, metabolisms, and microbiome conditions within the dental biofilm, consequently favoring the onset of dental caries disease. ${ }^{6}$ In this study, a high frequency and daily intake of sugary snacks and beverages was found among the schoolchildren, maybe due to the families' socioeconomic reality where carbohydrate-based foods are more accessible and to the fact that schoolchildren have multiple snacks during school hours, where they spend most of the day. However, a clear significant evidence linking their dietary habits to their caries experience could not be stablished. Similar results were found by Salgo $^{37}$ in a population of preschool children residing in Sucre Municipality, Caracas Venezuela, where no association was observed between the carbohydrates total daily intake (starches, sugars, and combined) and the presence of the disease (non-cavitated and cavitated lesions). Both this study's and Salgo's results in Venezuelan populations support what has been previously reported. ${ }^{38}$ 
The impact of other factors might have overwhelmed the effect of sugary snacks. It has been shown in various studies $^{39,40}$ that the presence of fluoride when evaluating the association between dental caries and diet could mask the effect of sugars, thus weakening the possible association between these variables. As previously discussed, a significant positive correlation was found between toothbrushing with fluoridated toothpastes and a healthy condition, possibly explaining why a significant correlation was not found between the intake of sugary snacks and beverages and dental caries experience $(p=0.081)$. Moreover, the fluoride presence might have reduced the progression of lesions to a lesser degree of severity, not allowing cavitation and consequently blinding the association. Since this phenomenon is a reflection of a masking done by the effect of fluoride, it does not imply that a high consumption of carbohydrates, in its different forms, is not an important risk factor for the onset of dental caries disease and lesion.

Finally, and also important to consider, is the general approach towards how the dietary habit was assessed, which lacked the inclusion of detailed specifications such as type of food, quantities and portions, and nutrient availability different from sugars (proteins, lipids, and other carbohydrates). As previously mention, diet is considered to modulate dental caries and as so it must be further studied using well designed and validated diet questionnaires that could accurately supplement the CRA.

Based upon the results found in this study, and from the point of view of the clinical and dental public health application, implementing oral health education programs targeting dental caries disease and lesion as well as associated risk factors seems necessary. Additionally, it is also considered necessary to carry out research with the most modern detection criteria to give results consistent with the situation of the disease in our schoolchildren. The results of this study will pave the way for conducting a large-scale research in the country with a larger sample size that involves more specific detection techniques and detailed risk factors assessment, required to give a representative image of the national caries experience scenario and associated factors. Ultimately, it is necessary that public policies and preventive programs that have community-based participation and alignment with local cultures are developed and implemented in schools where oral health primary and secondary prevention methods may be employed to manage dental caries disease in vulnerable communities.

\section{Conclusion}

These results suggest a severe dental caries experience with a statistically significant association between the health condition and toothbrushing with fluoridated toothpaste (1450 ppm) more than once a day and a positive standardized residual of 2.1 in schoolchildren that experience caries lesion that never brushed their teeth.

\section{Acknowledgements}

The authors want to express their most sincere thanks to: Gabriela Labastidas; Edwin Jardim; Johanaise Parra; Sharay Pacheco, Noribel Deyan (Internship Students at Salud Chacao), Dra Corina Aristimuño (Academic Coordinator of the Internship Program at Central University of Venezuela), Dr. Osman Mota (General Coordinator of the Dentistry Department at Salud Chacao and Field Coordinator of the Internship Program) "Sagrado Corazon de Jesus" School at Chacao Municipality, their Principal and teachers, Jose Torres (Statistics Consultant).

\section{References}

1. Rojas-Sánchez F, Cedeño J, Rivera H, Montero M, Acevedo AM. Prevalencia de caries dental en poblaciones indígenas del Municipio Autana, edo Amazonas, Venezuela. Odous Científica. 2018 ene-jun;19(1):8-18.

2. Tinanoff N, Baez RJ, Diaz Guillory C, Donly KJ, Feldens CA, McGrath C, et al. Early childhood caries epidemiology, aetiology, risk assessment, societal burden, management, education, and policy: global perspective. Int J Paediatr Dent. 2019 May;29(3):238-48. https://doi.org/10.1111/ipd.12484 
3. Machiulskiene V, Campus G, Carvalho JC, Dige I, Ekstrand KR, Jablonski-Momeni A, et al. Terminology of dental caries and dental caries management: consensus Report of a Workshop Organized by ORCA and Cariology Research Group of IADR. Caries Res. 2020;54(1):7-14. https://doi.org/10.1159/000503309

4. Takahashi N, Nyvad B. Caries ecology revisited: microbial dynamics and the caries process. Caries Res. 2008;42(6):409-18. https://doi.org/10.1159/000159604

5. Baelum V. Caries management: technical solutions to biological problems or evidence-based care? J Oral Rehabil. 2008 Feb;35(2):135-51. https://doi.org/10.1111/j.1365-2842.2007.01784.x

6. Gomez J, Ellwood RP, Martignon S, Pretty IA. Dentists' perspectives on caries-related treatment decisions. Community Dent Health. 2014 Jun;31(2):91-8. https://doi.org/10.1922/CDH_3341Gomez08

7. World Health Organization. WHO oral health country/area profile. Geneva: World Health Organization;2020 [cited 2020 Nov 3] Available from: http://www.whocollab.od.mah.se/index.html

8. Cova R, Lozada I. Estudio para la planificación integral de la odontología en Venezuela: area de salud oral 1967-1972. Venezuela: Ministerio de Sanidad y Asistencia Social;1972.

9. Mijares Gil A. Estudio sobre condiciones de vida de la población venezolana: aspectos odontológicos. FUNDACREDESA. Colegio de Odontólogos de Venezuela; 1995.

10. Rivera LE, Acevedo AM, Núñez A. Estudio basal de prevalencia de caries y fluorosis dental en niños escolarizados: informe final. Maracaibo: Organización Panamericana de la Salud; 1998.

11. Contreras MA. Fluoruración de Acueductos y la salud de los niños. In: VI Convención de Clubes Escolares de Nutrición; Caracas; 1952.

12. Morón Borjas A, Córdoba Y. Perfil epidemiológico bucal de las etnias venezolanas. Primer reporte nacional. Ciencia Odontológica. 2008;5(3):11.

13. Yee R, Sheiham A. The burden of restorative dental treatment for children in Third World countries. Int Dent J. 2002 Feb;52(1):1-9. https://doi.org/10.1111/j.1875-595X.2002.tb00589.x

14. Twetman S. Caries risk assessment in children: how accurate are we? Eur Arch Paediatr Dent. 2016 Feb;17(1):27-32. https://doi.org/10.1007/s40368-015-0195-7

15. American Academy of Pediatric Dentistry. Caries risk assessment and management for infants, children, and adolescents. Reference Manual 2015-2016. Pediatr Dent. 2015;37(special issue):132-9.

16. Ramos-Gomez F, Ng MW. Into the future: keeping healthy teeth caries free: pediatric CAMBRA protocols. J Calif Dent Assoc. 2011 Oct;39(10):723-33.

17. Bratthall D, Hänsel Petersson G. Cariogram: a multifactorial risk assessment model for a multifactorial disease. Community Dent Oral Epidemiol. 2005 Aug;33(4):256-64. https://doi.org/10.1111/j.1600-0528.2005.00233.x

18. Gao XL, Hsu CY, Xu Y, Hwarng HB, Loh T, Koh D. Building caries risk assessment models for children. J Dent Res. 2010 Jun;89(6):637-43. https://doi.org/10.1177/0022034510364489

19. Zukanović A. Caries risk assessment models in caries prediction. Acta Med Acad. 2013 Nov;42(2):198-208. https://doi.org/10.5644/ama2006-124.87

20. Petersson GH, Isberg PE, Twetman S. Caries risk assessment in school children using a reduced Cariogram model without saliva tests. BMC Oral Health. 2010 Apr;10(1):5. https://doi.org/10.1186/1472-6831-10-5

21. Organización de los Estados Americanos (OEA). Comisión Interamericana para el Control del Abuso de Drogas (CICAD). Informe del diagnóstico situacional participativo (análisis situacional) del municipio chacao del Distrito Metropolitano de Caracas. 2006 [cited 2020 Mar 15]. Available from: http://www.cicad.oas.org/fortalecimiento_institucional/savia/PDF/diagnosticofinal/DIAGNOSTICO_final_chacao.pdf

22. Hernan C. Sociedad y estratificación: método Graffar-Méndez Castellano. Caracas: Fundacredesa; 1994.

23. World Health Organization- WHO. WHO oral health surveys: basic methods. 5th ed. Monts: WHO; 2013. p. 42-7.

24. Cohen J. A Coefficient of agreement for nominal scales. Educ Psychol Meas. 1960;20(1):37-46. https://doi.org/10.1177/001316446002000104

25. Featherstone JD, Domejean-Orliaguet S, Jenson L, Wolff M, Young DA. Caries risk assessment in practice for age 6 through adult. J Calif Dent Assoc. 2007 Oct;35(10):703-7.

26. Martignon S, Pitts NB, Goffin G, Mazevet M, Douglas GV, Newton JT, et al. CariesCare practice guide: consensus on evidence into practice [published correction appears in Br Dent J. 2019 Dec;227(11):988]. Br Dent J. 2019 Sep;227(5):353-62. https://doi.org/10.1038/s41415-019-0678-8

27. Pitts NB, Zero DT, Marsh PD, Ekstrand K, Weintraub JA, Ramos-Gomez F, et al. Dental caries. Nat Rev Dis Primers. 2017 May;3(1):17030. https://doi.org/10.1038/nrdp.2017.30

28. World Health Organization. Guideline: sugar intake for adults and children. 2015 [cited 2020 dec 22] Available from: www.who.int/nutrition/publications/guidelines/sugars_intake/en/ 
29. Skeie MS, Raadal M, Strand GV, Espelid I. The relationship between caries in the primary dentition at 5 years of age and permanent dentition at 10 years of age: a longitudinal study. Inter Jour of Ped Dent. 2006 May; 16(3):152-60. https://doi.org/10.1111/j.1365-263X.2006.00720.x

30. Schmoeckel J, Gorseta K, Splieth CH, Juric H. How to intervene in the caries process: early childhood caries: a systematic review. Caries Res. 2020;54(2):102-12. https://doi.org/10.1159/000504335

31. Acevedo AM, Machado C, Rivera LE, Wolff M, Kleinberg I. The inhibitory effect of an arginine bicarbonate/calcium carbonate CaviStat-containing dentifrice on the development of dental caries in Venezuelan school children. J Clin Dent. 2005;16(3):63-70.

32. Wang LJ, Tang R, Bonstein T, Bush P, Nancollas GH. Enamel demineralization in primary and permanent teeth. J Dent Res. 2006 Apr;85(4):359-63. https://doi.org/10.1177/154405910608500415

33. Montero M, Rojas-Sánchez F, Socorro M, Torres J, Acevedo AM. Experiencia de caries y fluorosis dental en escolares que consumen agua con diferentes concentraciones de fluoruro en Maiquetía, Estado Vargas, Venezuela. Invest Clin. 2007 Mar;48(1):5-19.

34. Llena C, Calabuig E, Sanz JL, Melo M. Risk factors associated with carious lesions in permanent first molars in children: a seven-year retrospective cohort study. Int J Environ Res Public Health. 2020 Feb;17(4):1421. https://doi.org/10.3390/ijerph17041421

35. Hujoel PP, Hujoel MLA, Kotsakis GA. Personal oral hygiene and dental caries: a systematic review of randomised controlled trials. Gerodontology. 2018;35(4):282-9. https://doi.org/10.1111/ger.12331

36. ten Cate JM, Featherstone JD. Mechanistic aspects of the interactions between fluoride and dental enamel. Crit Rev Oral Biol Med. 1991;2(3):283-96. https://doi.org/10.1177/10454411910020030101

37. Salgo N. Asociación entre el consume de carbohidratos y la caries dental en niños preescolares. Trabajo especial de grado presentado ante la Universidad Central de Venezuela. Fac Odontol. 2003;February 16, 2021:76-7.

38. Burt BA, Szpunar SM. The Michigan study: the relationship between sugars intake and dental caries over three years. Int Dent J. 1994 Jun; 44(3):230-40.

39. Köning KG. Changes in the prevalence of dental caries: how much can be attribute to change in diet? Caries Res. 1990;24(1 suppl):16S-8S. https://doi.org/10.1159/000261315

40. Burt BA, Pai S. Sugar consumption and caries risk: a systematic review. J Dent Educ. 2001 Oct;65(10):1017-23. https://doi.org/10.1002/i.0022-0337.2001.65.10.tb03444.x 